\title{
AN INTERPRETATION OF 'INTERNAL ARMED CONFLICT' UNDER EU ASYLUM LAW - HOW FAR IS TOO FAR? DIAKITÉ CASE COMMENTS
}

\section{Marta Szuniewicz*}

Due to the narrow definition of 'a refugee' in international law, persons fleeing their country of origin in consequence of an armed conflict are not covered by the provisions of the Geneva Convention of 1951 unless they meet all the conditions stipulated in the abovementioned treaty. Under EU law, however, such persons may be entitled to additional protective status, i.e. temporary protection or subsidiary protection. In the latter regard, the EU 'Qualification Directive' of 2004 provides international protection for persons who, if returned to their country of origin, would face a real risk of suffering serious harm due to indiscriminate violence in situations of an armed conflict. However, the vagueness of the terms used permits a variety of interpretations of the relevant legal provisions. One of the main problems is whether, for the purpose of granting subsidiary protection, it is the criteria established by international humanitarian law (IHL) that should form the basis for assessing the existence of an armed conflict. This issue was the essence of the question submitted in 2012 to the Court of Justice of the European Union (CJEU) in reference for a preliminary ruling. The judgment issued in 2014 in the case of Diakité ${ }^{1}$ was expected

* Marta Szuniewicz, PhD, Institute of National Security, Faculty of Command and Maritime Operations, Polish Naval Academy in Gdynia.

1 Aboubacar Diakité v. Commisaire general aux réfugiés et aux apatrides, Case no C-285/12, Judgment of 30.1.2014, ECLI:EU:C:2014:39. 
to clarify those questions; however, the Court's findings and assessments proved difficult to follow in a number of points. The aim of this paper is to examine this judgment in context of IHL and EU asylum law and to determine its weaknesses.

\section{$* * *$}

Council Directive 2004/83/EC of 29.4.2004 on minimum standards for the qualification and status of third country nationals or stateless persons as refugees or persons who otherwise need international protection and the context of the protection granted ${ }^{2}$ (the so-called 'Qualification Directive') introduced subsidiary protection as complementary to the 1951 Refugee Convention protection. ${ }^{3}$ This EU act relies on granting a particular legal status to a person who faces a risk of serious harm in his or her country of origin and is unable to enjoy the protection of that home country. Although such a person does not meet the requirements for refugee protection, he or she cannot be returned to their home country due to the States' obligation to protect human rights and those arising out of the principle of non-refoulement. ${ }^{4}$

According to Article 2(e) of the Directive:

[a] person eligible for subsidiary protection' is 'a third country national or a stateless person who does not qualify as a refugee but in respect of whom substantial grounds have been shown for believing that the person concerned, if returned to his or her country of origin,

2 O.J. 30.9.2004, L 304, p. 12.

3 According to the preamble to Directive 2004/83, the main objective of this act is to complement rules regarding refugee status by measures on subsidiary forms of protection to any person in need of international protection, and 'to ensure that Member States apply common criteria for the identification of persons genuinely in need of international protection' (preamble, recitals 5 and 6).

4 For more, see UNHCR, Complementary forms of protection, UN Doc. EC/GC/01/18 (4.9.2001); UNHCR, Complementary forms of protection: their nature and relationship to the international refugee regime, UN Doc. EC/50/SC/CRP.18, Standing Committee, 18th meeting (9.6.2000); J. McAdam, The European Union Qualification Directive: the creation of a subsidiary protection regime, 'International Journal of Refugee Law' 2005, vol. 17, no 3; G. Noll, Fixed Definitions or Framework Legislation? The Delimitation of Subsidiary Protection ratione personae, 'New Issues in Refugee Research', Working Paper no 55 (February 2002), http://www.refworld.org/pdfid/4ff54e8b2.pdf [accessed 17.12.2014]. 
or in the case of a stateless person, to his or her country of former habitual residence, would face a real risk of suffering serious harm as defined in Article 15 (...) and is unable, or, owing to such risk, unwilling to avail himself or herself of the protection of that country.

The definition of 'serious harm' includes the presence of a "serious and individual threat to a civilian's life or person by reason of indiscriminate violence in situations of international or internal armed conflict". Hence, the main problem revolves around the questions of how to determine the threat that a person may become a victim of 'indiscriminate violence', and of whether the situation involved is in fact a case of an 'internal armed conflict'.

Given the nature of its formulation, Article 15(c) has given rise to much uncertainty in its practical application, which now varies substantially across the Member States. ${ }^{6}$ In their practice, the States have shown a tendency to narrow the scope of Article 15(c), in particular so as to interpret the term 'individual threat' in a highly restrictive manner. ${ }^{7}$ In the States' opinion, the risks to which a population of a country or a section of the population are generally exposed do not normally create, in themselves, an individual threat that would qualify as serious harm. Therefore, for the purpose of being granted subsidiary protection, an applicant would be required to prove that they were personally targeted, i.e. that they face a greater risk of harm than the rest of the population. Meanwhile, the Office of the United Nations High Commissioner for Refugees (UNHCR) has recognized that such practices render the protection offered by the Directive illusory for many persons. ${ }^{8}$

5 Qualification Directive, supra, Article 15(c).

6 See, for example, Directive 2004/83 Qualification Directive Synthesis Report (2007), p. 1, at pp. 20, 75; European Parliament, Briefing Note on Implementation of the Qualification Directive 'Minimum standards relating to eligibility for refugee status or international protection and content of this status - assessment (summary) of the implementation of the 2004 directive and proposals for a common European regime on asylum' (September 2008).

7 ECRE, Comments on the European Commission Proposal to recast the Qualification Directive, March 2010, p. 1, at p. 15; see also M. Garlic, UNHCR and the Implementation of the EC Qualification Directive, [in:] K. Zwaan (ed.), 'The Qualification Directive: Central Themes, Problem Issues, and Implementation in Selected Member States', Nijmegen 2007, 59 at p. 62.

8 UNHCR Study on the Implementation of the Qualification Directive 'Asylum in the European Union', November 2007, p. 1, at pp. 11, 15. 
Not accidentally, then, the first preliminary reference to the EU Court concerned this particular issue. In 2009, the EU Court stressed in the Elgafaji case that, contrary to the types of harm specified in Art. 15(a) and (b), which specifically target the applicant, Art. 15(c) of the Qualification Directive "covers a more general risk of harm" by using the term 'indiscriminate.' In line with that interpretation, the term 'individual' used in Art. 15(c) is to be understood as covering harm to all civilians, where violence reaches levels sufficient to give 'substantial grounds' to believe that a civilian, if returned, would face a real risk solely on the basis of being present in the country.

Interpretations also vary as regards the term 'internal armed conflict' used in Article 15(c). ${ }^{10}$ Since no agreed definition of this concept exists in international law, the term has not been uniformly understood across the States and has received diverse application. The review of practices undertaken in this respect by EU Member States indicates that the States do in fact rely on IHL norms in ascertaining whether an 'internal armed conflict' exists. ${ }^{11}$ Therefore the Diakité case has significant importance, since the Court was asked if the concept of 'internal armed conflict', as specified in Article 15(c), is to follow the IHL definition or to be understood as a term with an autonomous meaning within the EU legal order (EU asylum law).

The judgment was delivered in response to a request for a preliminary ruling pursuant to Article 267 TFEU, made by the Conseil d'État (Belgium) during proceedings between Mr. Diakité and the Commissioner General for Refugees and Stateless Persons, relating to a decision which refused to grant him subsidiary protection. The case concerned Mr. Diakité, a Guinean national, who had repeatedly applied for asylum in Belgium due to having sustained violence and repression in his country of origin. In 2008, he unsuccessfully applied for asylum, invoking the repression and violence that he had endured in his country of origin by reason of having

9 Elgafaji v. Sttatssecretaris van Justitie (Netherlands), Case no C-465/07, Judgment of 17.2.2009, ECLI:EU:C:2009:94, at paras 33-34.

10 L. Jakuleviciene, Is there a need for extension of subsidiary protection in the European Union Qualification Directive?, 'Jurisprudence' 2010, vol. 2, p. 215, at p. 226. As the author notes, "[ $t$ ]he situation in parts of Iraq was considered as 'internal armed conflict' in France, but not in Sweden where it was described as a 'severe conflict'. Whilst the Swedish authorities considered the conflict in Chechnya as an 'internal armed conflict', the Slovak authorities did not."

11 Opinion of Advocate General Mengozzi in case Diakité (18.7.2013), point 18, where he notes that "although starting from different premises (...) [States] in practice arrive at largely convergent understandings of the term". 
participated in protest movements against the ruling regime. In 2010, he was once again refused to be recognized as entitled to refugee status and subsidiary protection on the ground that, at that time, no situation of indiscriminate violence or armed conflict existed in Guinea. Despite an appeal lodged by the applicant, the refusal decision was upheld based on findings that the condition of existence of armed conflict in the applicant's country of origin was not met. That line of argumentation was contested by Mr. Diakité in his cassation appeal before the Conseil d'État. He argued that the decision erroneously relied on the definition of 'armed conflict', as defined in international humanitarian law (IHL) and as construed by the International Criminal Tribunal for the Former Yugoslavia (ICTY) in the Tadic case. ${ }^{12}$ Due to serious doubts whether the term 'armed conflict' used in Article 15(c) of Directive 2004/83 may be interpreted independently and, as a consequence, may have a different meaning from the concept of 'armed conflict' elaborated in the ICTY's case law, the Belgian Conseil d'État decided to refer to the Court of Justice a request for a preliminary ruling on the following questions:

[m]ust Article 15(c) of [Directive 2004/83] be interpreted as meaning that that provision offers protection only in a situation of "internal armed conflict", as interpreted by international humanitarian law, and, in particular, by reference to Common Article 3 of the four Geneva Conventions (...)?';

And:

'[i]f the concept of "internal armed conflict" referred to in Article 15(c) of [Directive 2004/83] is to be given an interpretation independent of Common Article 3 of the four Geneva Conventions..., what, in that case, are the criteria for determining whether such an "internal armed conflict" exists?

Since Directive 2004/83 contains no definition of an 'armed conflict', it seems indispensable to refer to IHL. The Court begins its reasoning with the statement that the term used in EU law (i.e. 'internal armed conflict') does not correspond directly with the phraseology provided for in IHL treaties (i.e. 'armed conflict not of an international character'). Therefore,

12 The Prosecutor v. Dusko Tadić (aka "Dule”), Case no IT-94-1-AR72, Judgment of the Appeals Chamber of the International Criminal Tribunal for the Former Yugoslavia of 2.10.1995, at para 67 . 
due to different concepts of a non-international armed conflict (NIAC) being implemented in both areas, their scope should also be differentiated. ${ }^{13}$ Taking this point even further, paragraph 20 of the judgment indicates that EU legislation uses the phrase 'internal armed conflict' as opposed to [emphasis added - M.Sz.] the concepts on which international humanitarian law is based"14. That stipulation led to the following conclusion:

[t]he EU legislature wished to grant subsidiary protection not only to persons affected by 'international armed conflicts' and by 'armed conflict not of an international character', as defined in international humanitarian law, but also to persons affected by internal armed conflict, provided that such conflict involves indiscriminate violence. In that context, it is not necessary for all the criteria referred to in Common Article 3 of the four Geneva Conventions and Article 1(1) of Protocol II of 8 June 1977, which develops and supplements that article, to be satisfied. ${ }^{15}$

Consequently, the Court stressed that "since Directive 2004/83 does not define 'internal armed conflict', the meaning and scope of that phrase must, as the Court has consistently held, be determined by considering its usual meaning in everyday language, while also taking into account the context in which it occurs and the purposes of the rules of which it is part" ${ }^{16}$ The Court also recalled its previous relevant case law. ${ }^{17}$ The CJEU acknowledged that, for the purpose of applying Article 15(c) of Directive 2004/83,

13 Judgment Diakité, supra, at para 20. In his Opinion, Advocate General Mengozzi stressed that even if terms 'internal armed conflict', 'armed conflict not of an international character', and 'non-international armed conflict', which appear, respectively, in Article 15 (c) of the Qualification Directive, Common Article 3 of the Geneva Conventions, and Protocol II, are "semantically almost identical", it "does not (...) in itself lead to the conclusion that those concepts must be given the same interpretation" [para 19 of the opinion].

14 Judgment Diakité, supra, at para 20.

15 Ibid., at para 21.

16 Ibid., at para 27. It is a well-established line of CJEU's legal reasoning; for more see M. Szuniewicz, Interpretacja prawa wspólnotowego - metody i moc wiążąca wykładni ETS [An interpretation of EU law - methods and binding force of ECJ legal reasoning], 'Studia Prawnicze' 2006, no 1, p. 23, at pp. 23-52, passim.

17 CJEU referred to Friederike Wallentin-Hermann v. Alitalia - Linee Aeree Italiane SpA, Case no C-549/07, Judgment of 22.12.2008, ECLI:EU:C:2008:771, at para 17, and Josef Probst v. mr.nexnet GmbH, Case no 119/12, Judgment of 22.11.2012, ECLI:EU:C:2012:748, at para 20. 
[a]an internal armed conflict exists (...) if a State's armed forces confront one or more armed groups or if two or more armed groups confront each other. It is not necessary for that conflict to be categorised as "armed conflict not of an international character" under international humanitarian law; nor is it necessary to carry out, in addition to an appraisal of the level of violence present in the territory concerned, a separate assessment of the intensity of the armed confrontations, the level of organisation of the armed forces involved or the duration of the conflict. ${ }^{18}$

One could argue that it was this erroneous preliminary assessment that led the Court to reach incorrect conclusions.

The first fundamental mistake made by the CJEU is to suggest that the terms 'internal armed conflicts' and 'non-international armed conflict' differ with respect to their scope and the types of situations they cover. The term 'internal armed conflict' is not used in IHL instruments which, as noted above, use the phrase 'armed conflict not of an international character'. Nevertheless, both terms are commonly accepted and used interchangeably throughout international law studies as opposed to being limited to the single concept of an 'armed conflict of an international character'. Within the international legal framework, there is no universal consensus over an explicit definition of 'armed conflict', a situation that has allowed a wide range of varying definitions of 'internal armed conflict' to be offered in academic literature. According to Lassa Oppenheim, "[a] civil war exists when two opposing parties within a state have recourse to arms for the purpose of obtaining power in the state, or when a large portion of the population of a state rises in arms against the legitimate government". ${ }^{19}$ Leslie C. Green defines "[a] non-international armed conflict [as] one in which the governmental authorities of a state are opposed by groups within that state seeking to overthrow those authorities by force of arms". ${ }^{20}$ Still other scholarly voices propose that an "[i]nternal armed conflict can be defined as the use of armed force within the boundary of one state between one or more armed groups and the acting government, or between such groups". ${ }^{21}$ Experts at the International Institute

18 Judgment Diakité, supra, at para 35.

19 L. Oppenheim and H. Lauterpacht, International Law - a treatise, London 1952, vol. II, p. 209.

20 L.C. Green, The Contemporary Law of Armed Conflicts, Manchester, New York 1993, p. 303.

21 Eve La Haye, War Crimes in Internal Armed Conflicts, Cambridge 2008, p. 5. 
of Humanitarian Law offer a definition which emphasizes the fact that "non-international armed conflicts are armed confrontations occurring within the territory of a single State and in which the armed forces of no other State are engaged against the central government". ${ }^{22}$ A review of the literature suggests that the basic elements of the NIAC definition are widely recognized and unanimously agreed on; namely, that the acts of violence that take place in a territory of one country are of greater intensity than 'internal disturbances and tensions'.

Therefore, since both terms are extensively used by the International Committee of the Red Cross (ICRC), International Institute of Humanitarian Law, legal scholars and international criminal courts, does the need really exist to distinguish between 'non-international armed conflict', as defined in IHL, and 'internal armed conflict' under EU asylum law? It appears reasonable to argue that there are no justified grounds to attribute the latter terms with any different meaning or scope than that found within the IHL field of application. Moreover, such a distinction is dangerous and potentially harmful to international law (e.g. by increasing its fragmentation) and to activities undertaken for the provision of international protection to all persons in need.

One of the reasons why the CJEU arrived at such a conclusion is a misunderstanding and confusion of terms. The problem is essentially the matter of the fact that IHL distinguishes between different types of internal conflict, but such a distinction is made only for the purpose of assessing the applicability of various instruments, which lay down different conditions that trigger their applicability. This stands in marked contrast to defining NIAC for the purpose of the applicability of particular IHL instruments, which set up different thresholds of intensity and character of the parties to the conflict in order to specify which types of armed conflicts they apply to. Two major sets of international rules applicable to the situation of internal armed conflicts are: Common Article 3 to the four Geneva Conventions of $1949^{23}$ and Additional Protocol II of $1977 .{ }^{24}$ Each

22 International Institute of Humanitarian Law, The Manual of the Law of NonNational Armed Conflict. With Commentary, Sanremo 2006, p. 2.

${ }^{23}$ Convention (I) on Wounded and Sick in Armed Forces in the Field (Geneva, 12.8.1949); Convention (II) on the Wounded, Sick and Shipwrecked of Armed Forces at Sea (Geneva, 12.8.1949); Convention (III) on Prisoners of War (Geneva, 12.8.1949); and Convention (IV) relative to the Protection of Civilian Persons in Time of War (Geneva, 12.8.1949).

24 Protocol Additional to the Geneva Conventions of 12 August 1949, and relating to the Protection of Victims of Non-International Armed Conflicts (Protocol II), Geneva, 
set is dedicated to armed conflicts of varying intensity levels of internal violence and each stipulates a different threshold beyond which it starts to operate. Common Article 3 merely requires that the armed conflict not be of 'an international character' and occurs "in the territory of one of the High Contracting Parties". The threshold is higher under Additional Protocol II, which only applies to conflicts between the armed forces of a High Contracting Party "and dissident armed forces or other organized armed groups which, under responsible command, exercise such control over a part of the territory as to enable them to carry out sustained and concerted military operations".

Despite the various thresholds for the applicability of particular IHL and international criminal law instruments, it remains unquestionable that internal violence must reach a sufficient level of intensity before it may be qualified as constituting an 'armed conflict'. In fact, a question of a paramount importance is how a non-international armed conflict is to be distinguished from lesser forms of collective violence, such as civil unrest, riots, isolated acts of terrorism and other sporadic acts of internal violence. ${ }^{25}$ Undoubtedly, to pinpoint the threshold of internal violence beyond which a situation becomes a case of 'armed conflict' is a precarious enterprise. For this reason, IHL doctrine seeks to locate and identify factors that may facilitate such an assessment.

In essence, IHL requires that two criteria be met for there to be a non-international armed conflict: the armed groups involved must show at least a minimum degree of organization and the armed confrontations must reach at least a minimum level of intensity. ${ }^{26}$ The fulfilment of such criteria is determined on a case-by-case basis, by weighing up a number of factual indicators. The level of the intensity of violence is determined based on a range of indicators, such as the duration and gravity of the armed clashes, the type of government forces involved, the number of fighters and troops involved, the types of weapons used, and the extent of the damage and casualties caused. The level of organization of the armed group is as-

\subsubsection{7.}

25 As was specifically expressed in Article 2.2. of Additional Protocol II.

${ }^{26}$ In the early 1960 s, a commission of experts provided guidelines on this matter stressing that "the existence of an armed conflict, within the meaning of article 3, cannot be denied if the hostile action, directed against the legal government, is of a collective character and consists of a minimum amount of organization"; see Commission of Experts report on the question of aid to the victims of internal conflicts (Geneva, 25-30.10.1962), 'International Review of the Red Cross' 1963, vol. 3, at p. 81. 
sessed by taking account of the factors such as the existence of a chain of command, the capacity to transmit and enforce orders, the ability to plan and launch coordinated military operations, and the capacity to recruit, train and equip new fighters. ${ }^{27}$ However, assessing the existence of such a defined armed conflict is subject to the political will of States and other international actors. ${ }^{28}$ Even if they follow the set of guidelines provided by international law while recognizing a situation as a case of an armed conflict, they remain inconsistent in respect of the indicators they propound. ${ }^{29}$

Moreover, in paragraphs 22 and 23 of the Diakité judgment, where remarks are made concerning the purpose for which IHL norms were created, the Court holds that IHL is not designed:

to provide for international protection to be granted to certain civilians who are outside both the conflict zone and the territory of the conflicting parties. As a consequence, the definitions of 'armed conflict' provided in IHL were not designed to identify the situations in which such international protection would be necessary and would thus have to be granted by the competent authorities of the Member States ${ }^{30}$.

This part of the judgment seems completely irrelevant to the merits of the case and the essence of the question referred by the domestic court. Both the Advocate General in his Opinion and the Court of Justice in its judgment noted that IHL and the subsidiary protection regime introduced in the Directive "pursue different aims and establish quite distinct protection mechanisms". ${ }^{31}$ This, however, is obvious and in no way does such

27 See Internal conflicts or other situations of violence - what is the difference for victim?, an interview with K. Lawand (ICRC), 12.12.2012, available at: https://www.icrc.org/eng/ resources/documents/interview/2012/12-10-niac-non-international-armed-conflict.htm [accessed 12.12.2014].

28 L. Moir, The Law of Internal Armed Conflict, Cambridge 2004, pp. 3 et seq.

29 R. Barquero, The [New] Thresholds of Non-International Armed Conflict-A Product of Jurisprudential Provenance? An assessment of the role that international case law has played in altering the criteria used for the determination of the existence of a non-international armed conflict, available at: http://www.academia.edu/4663155/The_New_Thresholds_of_NonInternational_Armed_Conflict--_A_Product_of_Jurisprudential_Provenance [accessed 10.1.2015], p. 1, at p. 4.

30 Judgment Diakité, supra, at para 23.

31 Ibid., at para 24. 
disregard for those distinct areas - governed by IHL and the Directive bring the Court closer to answering the referred question. ${ }^{32}$

Do the norms laid down in the Directive actually require fulfilment of the conditions for applying IHL? In fact, neither article 15 nor any of the Directive's other provisions mention IHL at all; instead, they only require that a fear is related to certain acts that must take place during an armed conflict (specifically, "threat to a civilian's life or person by reason of indiscriminate violence in situations of international or internal armed conflict"). Moreover, since the Directive mentions both 'international' and 'internal' armed conflicts in the very same phrase, it is the issue of armed conflict and the question of its presence that should be given primary importance, i.e. when domestic violence reaches the minimum threshold of intensity sufficient to be recognized as an armed conflict. This is the formula of 'an armed conflict of non-international character' from Common Article 3 of the Geneva Conventions, that is the lowest intensity of internal violence sufficient to be qualified as an armed conflict. Similarly, the question submitted to the Court of Justice also refers to Common Article 3 of the four Geneva Conventions. Therefore, insofar as concerns the applicability of the Directive, it is not even necessary to provide an exact definition of what an 'internal conflict' is, but only to ascertain the threshold above which one may speak of an armed conflict (i.e. to distinguish it from other acts of internal violence).

Another matter of doubt is the reasoning adopted by the Belgian asylum organs in their decision regarding Mr. Diakité's application. To assess whether the examined case fell within the definition of 'armed conflict', which constitutes a sine qua non condition for recognizing the applicant under Article 15(c) of the Qualification Directive - as a person eligible for subsidiary protection, the organs presented a line of argumentation that invoked the case law of the ICTY. Indeed, this poses the question of whether this was not a case of excessive zeal demonstrated by both the asylum organs and the domestic courts. ${ }^{33}$ Arguably, since the Directive does not require that the criteria for applying IHL be established, and instead focuses solely on the existence of an internal armed conflict, one should not venture into the complex matter of determining the various intensities of

32 Ibid., at para 26.

33 For the reason that relevant domestic regulations quote the provisions of Article 15 almost verbatim. 
internal armed conflict which would be required for the purpose of applying particular IHL instruments.

For the purpose of applying Article 15(c), it suffices to rely on the basic doctrine concept of NIAC that is universally accepted in IHL. However, while earlier analyses of IHL stressed that two conditions are necessary for the existence of an armed conflict - namely, a certain degree of intensity of acts of violence and a certain degree of organization of the fighting parties - current attempts to define NIAC also require the identification of a number of additional requirements. For example, in the widely commented Tadic case ${ }^{34}$ (which was also referred to by the Belgian organs), the ICTY added an additional temporal requirement, i.e. the criterion of 'protracted armed violence. ${ }^{35}$ In determining whether (internal) armed conflict is present, contemporary analyses necessitate the existence of the following elements: territorial control, protracted armed violence, intensity of hostilities, and organization among the parties involved. ${ }^{36}$ Nevertheless, the existence of those elements depends on a range of different factors, which can vary with respect to the significance that is afforded to each criterion. ${ }^{37}$ However, these are all vague terms, and there is consistently no single, precise definition of 'armed conflict' and no exact assessment where its threshold lies.

On the grounds of the aforementioned considerations, the CJEU concluded that the finding that there is an armed conflict must not be made conditional upon the fact of armed forces involved having a certain level of organization, or upon the conflict lasting for a specific length of

34 In the Orić case, the Chamber the International Tribunal for the Former Yugoslavia stated that the Tadic formula is "well-settled in the jurisprudence of the Tribunal" (Prosecutor v. Naser Orić, Case no. IT-03-68-T, Judgment of 30.6.2006, at para 254). On the other hand, the new Tadić test is not unanimously applied even by the International Tribunal for the Former Yugoslavia and the chambers often refused to accept that such control of territory is a requirement for the existence of an armed conflict. But they always strongly emphasized the paramount importance of the intensity criterion (see, example, Prosecutor v. Limaj, Case no. IT-03-66-T, Judgment of Trial Chamber of 30.11.2005, at para 89 et seq.).

${ }^{35}$ See Opinion Diakité, supra, footnote 40. The same condition appears in Article $8(2)(f)$ of the Statute of the International Criminal Court ('armed conflicts not of an international character' means "armed conflicts that take place in the territory of a State when there is protracted armed conflict between governmental authorities and organized armed groups or between such groups").

36 See R. Barquero, op. cit., at p. 36.

37 Ibid., at p. 50. 
time: it is sufficient if the confrontations in which those armed forces are involved give rise to a certain level of violence. ${ }^{38}$ Consequently, the Court's answer to the question referred is that,

on a proper construction of Article 15(c) of Directive 2004/83, it must be acknowledged that an internal armed conflict exists, for the purposes of applying that provision, if a State's armed forces confront one or more armed groups or if two or more armed groups confront each other. It is not necessary for that conflict to be categorised as 'armed conflict not of an international character' under international humanitarian law; nor is it necessary to carry out, in addition to an appraisal of the level of violence present in the territory concerned, a separate assessment of the intensity of the armed confrontations, the level of organisation of the armed forces involved or the duration of the conflict. ${ }^{39}$

The CJEU concluded that, in accordance with the ordinary meaning of the term, an 'internal armed conflict' is deemed to exist if a State's armed forces confront one or more armed groups, or if two or more armed groups confront each other - without having to be classified as such under IHL. The Court has, therefore, interpreted the concept of 'internal armed conflict' autonomously in the EU asylum law context. Consequently, a lower burden of proof has been imposed on applicants for subsidiary protection, as there is no need to prove the presence of an 'internal armed conflict', as understood within the context of IHL.

The Court's position presents a risk that each situation wherein there exists a confrontation of armed forces will have to be classified as an armed conflict by domestic asylum authorities. This, in turn, would stand in complete contradiction to the usual meaning of 'armed conflict' given in Article 15(c) of the Directive because, as mentioned above, only such confrontations that have reached a minimal level of intensity can be qualified as such. In this context, the purpose of the conditions established under IHL is merely to further specify the level of internal violence above which the situation calls for qualification as an 'armed conflict'. The creation of a legal definition of NIAC - for instance, within the case law of the CJEU - will certainly serve the goal of harmonization, since providing

38 Judgment Diakité, supra, at para 34; it follows, in full, the observation presented in the Opinion of Advocate General (para 92).

39 Judgment Diakité, supra, at para 35. 
complementary protection to persons in need constitutes the main objective of EU asylum law.

Meanwhile, the stand taken by the judges not only failed to specify the scope for applying Article 15(c), but - by arriving at the conclusion that invoked an autonomous definition of an 'internal armed conflict' - only gave rise to further problems and doubt. Moreover, while rejecting the criteria developed within the doctrine of IHL, the Court failed to indicate the criteria for assessing the existence of armed conflict for the purpose of the Qualification Directive. As it happens, the CJEU did not answer the second question referred and did not specify the criteria for determining whether a third country national or a stateless person is eligible for subsidiary protection under Article 15(c) of Directive 2004/87. In this context, instead of shedding clarifying light on the matter, the Court's decision only further added to its excessive complexity.

Overusing the notion of 'autonomous concepts' in interpreting EU law appears to run contrary to the principle of the complementarity of international law: not only does it contribute to the already-deepening fragmentation of international law, but it constitutes yet another step on the way to making EU law an isolated island within an ocean of public international law. The Court's decision needs to be considered in a particularly cautious manner with regard to other areas of law, especially because the term 'armed conflict' is alien to EU law. Therefore, if it is borrowed, it should be adopted with its ordinary meaning and scope in mind. Meanwhile, the Court "warn[ed] against any mechanism resulting in the introduction to the context of that directive of concepts or definitions adopted in different contexts, even though they fall within the scope of EU law" ${ }^{40}$ Thus, one could well ask: how else should the existence of an internal armed conflict be determined outside the remit of IHL if not by referring to Article 3 of the Geneva Conventions, which is the very provision that covers situations just above the threshold of 'armed conflict'?

The CJEU, however, viewed the matter differently. Following a generally accepted model of interpretation, the Court stated that, in the absence of a legal definition, the meaning and scope of the term 'internal armed conflict' must "be determined by considering its usual meaning in everyday language, while also taking into account the context in which it occurs

40 See Bundesrepublik Deutschland v. B. and D., Joined Cases C-57/09 and C-101/09, Judgment of 9.11.2010, ECLI:EU:C:2010:661, at para 89 et seq. 
and the purpose of the rules of which it is part". ${ }^{41}$ In light of the above, the term refers to "a situation in which a State's armed forces confront one or more armed groups or in which two or more armed groups confront each other". ${ }^{42}$ This makes its wording identical to that of the general definition of NIAC reconstructed in IHL doctrine, which still nevertheless requires such confrontations to be distinguished from 'internal disturbances and tensions'. Meanwhile, the CJEU noted that the usual legal test for a NIAC, based on Additional Protocol II to the Geneva Conventions and the ICTY's Tadic decision, requires that non-state armed groups in the conflict reach a minimum threshold of organization, and that the violence be protracted and reach a minimal level of intensity. Consequently, it rejected those criteria as being suitable for the purpose of interpreting the provisions of the Qualification Directive. However, those conditions are more restrictive and were created to specify the scope of application of particular treaties and jurisdiction of international criminal courts.

As the Court noted, in order to be granted subsidiary protection under Article 15(c), it is necessary to show that there an armed conflict exists (whether international or internal) in the applicant's country of origin, but this applies only to the circumstances where:

confrontations between (...) armed groups (...) are exceptionally considered to create a serious and individual threat to the life or person of an applicant (...) because the degree of indiscriminate violence which characterizes those confrontations reaches such a high level that substantial grounds are shown for believing that a civilian, if returned to the relevant country or, as the case may be, to the relevant region, would - solely on account of his presence in the territory of that country or region - face a real risk of being subject to that threat. ${ }^{43}$

41 Judgment Diakité, supra, at para 27.

42 Ibid., at para 28.

43 Ibid., at para 30. In this part, the Court referred to its previous judgment in the Elgafaji case, in which it had stood in favor of a more general nature of that risk (para 43) and recalled that "the more the applicant is able to show that he is specifically affected by reason of factors particular to his personal circumstances, the lower the level of indiscriminate violence required for him to be eligible for subsidiary protection" (para 39). That led the Chamber of the Court in the Diakité case to the conclusion that "[i]n that context, it is not necessary, when considering an application for subsidiary protection, to carry out a specific assessment of the intensity of such confrontations in order to determine, separately from the appraisal of the resulting level of violence, whether the condition relating to armed conflict has been met" (para 32). In both cases the Court established an explicit, direct link between the risk that the applicant will be subject 
In his Opinion, which invoked the objective of minimum harmonization pursued by the Qualifications Directive, the Advocate General highly emphasized the unprecedented significance of a teleological interpretation of EU law. According to Mengozzi, literal interpretation "must not lead the Court to give preference to a restrictive interpretation of its provisions, particularly where it is a matter of determining the import of the concepts used to define the scope of the subsidiary protection regime". ${ }^{44}$ Moreover, he stressed the necessity for legal reasoning to take account of the "humanitarian considerations which underlie that regime, an expression of the values of respect for human dignity and respect for human rights". ${ }^{45}$

According to the Opinion of Advocate General, the application of Article 15(c) of the Qualifications Directive, read in conjunction with Article 2(e) thereof, cannot be dismissed from the outset on the sole ground that the situation in the applicant's country of origin does not satisfy all of the criteria used in IHL. Thus, cases "cannot be considered to be automatically excluded from the scope of those provisions" where, for example, armed violence is used unilaterally; the belligerents do not have the degree of organization required under IHL or do not exercise control over the territory; the government forces do not intervene in the conflict; there are no "protracted armed confrontations" within the meaning of IHL; or, further, where the situation falls within the scope of the concepts of 'internal disturbances' or 'internal tensions', as defined in IHL. ${ }^{46}$ However, that last suggestion could be argued to overstep the boundaries of acceptability, since it runs counter to the commonly-accepted rule that internal disturbances and tensions are not armed conflicts, but situations in which a lower level of internal violence exists. That line of interpretation would in fact contradict the concept of 'armed conflict' and the distinction between 'internal armed conflicts' and 'internal disturbances and tensions', since such situations fall below the threshold of an armed conflict. However, as stated by Mengozzi,

[a]ll these situations are capable of being covered by Article 15(c) of the Qualifications Directive where the degree of indiscriminate violence in the third country concerned at the time of taking a decision

to the harm defined in that article, on the one hand, and the degree of indiscriminate violence that characterizes the armed conflict taking place, on the other.

44 Opinion Diakité, supra, at point 95.

45 Ibid., at point 96.

46 Ibid., at para 92. 
on the application for subsidiary protection reaches a level such that there is a real risk to the life or person of the applicant if he or she is returned to his or her country of origin. ${ }^{47}$

Furthermore, the Advocate General suggested that the assessment be conducted in compliance with paragraph 39 of the judgment in the Elgafaji case.

The EU Qualification Directive introduced subsidiary protection regime in order to address the needs of persons that would otherwise be left unprotected, thereby closing a "protection gap" which existed in the legal regime designed to offer international protection for all persons in need. According to the European Ombudsman and representatives of human rights organizations, if the CJEU had interpreted 'internal armed conflict' in line with IHL, such a high threshold would not only have rendered the protection granted under EU law "illusionary" and "ineffective", but it would have also been incompatible with the very aim of subsidiary protection. ${ }^{48}$ The line of interpretation adopted by the CJEU in the Diakite case sought to loosen the requirements for qualifying persons as eligible for subsidiary protection under the Directive, and at embracing persons who cannot return to their country of origin due to internal violence which fails to reach a level sufficient for it to be qualified as 'armed conflict'. However, the question at hand is not whether such persons are in need of international protection (from the humanitarian perspective the answer is clearly 'yes'), but whether such persons fall within the scope of Article 15(c) - and here the answer is ' $n o$ '.

Although the objectives embodied in the preamble to EU legislative acts are of paramount importance, especially from the perspective of teleological interpretation, they should not be deemed to constitute legitimate grounds for departing from the clear wording of a given provision. Therefore, in this case, if one of the conditions for being granted subsidiary protection is the requirement to demonstrate the existence of a risk of serious harm that is due to a particular type of threat and that inspires an applicant's fears to return to his or her country of origin, one must not

47 Ibid., at para 93.

48 A. Teffera, Diakité: The CJEU interprets the concept of 'internal armed conflict' for the purpose of granting subsidiary protection under EU law (22.3.2014), http://www.asylumlawdatabase.eu/en/journal/diakit\%C3\%A9-cjeu-interprets-concept-\%E2\%80\%98internal-armed-conflict\%E2\%80\%99-purpose-granting-subsidiary [accessed 12.12.2014]. 
quote the recitals of the Directive's preamble to justify a departure from that requirement.

Making effective use of subsidiary protection requires the individualization of the risk of harm in a way similar to that set out in the Geneva Convention 1951 (albeit based on a different definition of persecution). Rather than a presence of general acts of violence or systematic violation of human rights, the Qualification Directive explicitly requires that a particular type of acts of violence (i.e. 'indiscriminate violence') be present during an armed conflict; otherwise, the terminology would have been used to echo that laid down in the 2001 EU Directive on temporary protection. This is because EU law has developed a different instrument for the protection of persons fleeing the violence caused by armed conflict, namely temporary protection, which provides "a short-term strategy" in cases of mass-influx. ${ }^{49}$ The Directive provides protection that embraces in particular "persons who have fled areas of armed conflict or endemic violence" and "persons at serious risk of, or who have been the victims of, systematic or generalized violations of their human rights". ${ }^{50}$ Divergent formulations contained in legal instruments adopted at the same stage of harmonization of the EU asylum law cannot be recognized as irrelevant.

In his Opinion, the Advocate General stressed that subsidiary protection is targeted at persons who have left the area where conflict is taking place and cannot return there because of the prevailing situation of generalized violence. ${ }^{51}$ The UNHCR and relevant non-governmental organizations emphasized the need to provide access to international protection

49 See J. Fitzpatrick, Temporary protection of refugees: elements of a formalized regime, 'American Journal of International Law' 2000, vol. 94, p. 279, at pp. 280, 287, and 296; J. Pirjola, Temporary protection as a future model for asylum?, 'Nordic Journal of International Law' 1995, vol. 64, p. 423, at pp. 425 and 427; K. Hailbronner, Temporary and local responses to forced migrations: a comment, 'Virginia Journal of International Law' 1994, vol. 35, p. 81, at pp. 90 and 95; UNHCR, Executive Committee, Note on international protection (A/AC.96/830), 7.9.1994, para 45; Council of Europe, Committee of Ministers, Recommendation R (2000) 9 on temporary protection (3.5.2000), preamble, recital 6.

50 Council Directive 2001/55/EC of 20 July 2001 on minimum standards for giving temporary protection in the event of a mass influx of displaced persons and on measures promoting a balance of efforts between Member States in receiving such persons and bearing the consequences thereof, O.J. 7.8.2001, L-212, Article 2(a) in conjunction with Article 2(c).

51 Opinion Diakité, supra, at para 67. 
for persons fleeing human rights violations. ${ }^{52}$ The problem, however, is that the Qualification Directive does not use the term "human rights violations" but, rather, that of "indiscriminate violence" in armed conflict. As a result, it not only requires such acts to occur during an armed conflict, but also strictly binds the nature of such violations with the conduct of hostilities. What 'indiscriminate violence' means should then be perceived from the perspective of IHL norms, which specify which attacks may be qualified as indiscriminate. Although the term 'violence' has a wider scope than 'attack', the essence of the adjective 'indiscriminate' can be derived from IHL provisions that prohibit indiscriminate attacks. Moreover, since other EU instruments use a more open formula - the EU Directive on temporary protection, for example, contains the phrase "systematic or generalized violations of (...) human rights" - a formulation that takes account of a more specific type of violation cannot be ignored. In line with the approach calling for a rational interpretation of the law, different formulations cannot be ascribed identical material scope. Not even teleological interpretation of the law, the idea of human rights protection, nor the principle of humanity can justify legal interpretation praeter legem.

The issue of interpreting EU law in compliance with international law should also be mentioned. Under Article 3(5) TEU, the European Union "shall contribute (...) to the strict observance and the development of international law" and "must respect international law in the exercise of its powers" ${ }^{53}$ Seen in this light, the principle of consistent interpretation applies to the Court when analyzing the relationships between international law and EU law. Thus, even though the European Union is not party to the Geneva Conventions and their Additional Protocols, their norms have been recognized by the International Court of Justice as expressing 'intransgressible principles of international customary law', ${ }^{54}$ and - as

52 A. Teffera, Diakité: The CJEU interprets the concept of 'internal armed conflict' for the purpose of granting subsidiary protection under EU law (22.03.2014), http://www.asylumlawdatabase.eu/en/journal/diakit\%C3\%A9-cjeu-interprets-concept-\%E2\%80\%98internal-armed-conflict\%E2\%80\%99-purpose-granting-subsidiary [accessed: 12.12.2014].

53 Opinion Diakité, supra, at para 23. As is well established in CJEU case law; see, for example, Anklagemyndigheden v. Peter Michael Poulsen and Diva Navigation Corp., Case C-286/90, Judgment of 24.11.1992, ECLI:EU:C:1992:453, at para 9; A. Racke GmbH \& Co. v. Hauptzollamt Mainz, Case C-162/96, Judgment of 16.6.1998, ECLI:EU:T:1998:175, at para 45 .

54 Legality of the Threat or Use of Nuclear Weapons, Advisory Opinion of International Court of Justice of 8.7.1996, ICJ Reports 1996, p. 226, at paras 79-80. 
such - they are binding. This is why the Court must guarantee a reading of EU law consistent with IHL principles. ${ }^{55}$

At the same time, however, the Court has warned in its case law "against any mechanism resulting in the introduction to the context of that directive of concepts or definitions adopted in different contexts, even though they fall within the scope of EU law". ${ }^{36}$ In fact, the principle of consistency seems to be of little relevance if the Court ignores IHL (which forms part of international law) in interpreting the term 'armed conflict', which is clearly fundamental to that branch of law. Therefore, provided that the objective of the Qualification Directive - as specified in the preamble - is to shape the institutionalized protection of persons who cannot be returned to their country of origin due to other obligations of Member States under instruments of international law to which they are party, how can one disregard the provisions of that very law in specifying the scope of such protection? This is not an issue of extending the range of beneficiaries by developing an instrument of EU secondary law (which is clearly permissible provided that the necessary political consensus is reached between the Member States within the EU organs responsible for establishing particular immigration and asylum instruments), but one of disregarding the terminology, institutions and conceptions of international law in expanding the subject matter of obligations arising therefrom; in other words, this is an issue of blatantly ignoring the legal framework established by that law.

In this context, the fundamental issue is to assess the threshold beyond which an 'armed conflict' exists, and to distinguish between an 'armed conflict' and 'internal tensions, disturbances or isolated acts of violence'. Such a level of intensity of domestic violence is required not only by IHL but also by the Qualification Directive, since it uses the phrase of 'internal armed conflict' rather than those of 'internal violence' or 'endemic violence', as the EU Directive on temporary protection does. Consequently, it would be an interpretation praeter legem to indicate that a lower level of internal violence should be embraced by the scope of Article 15(c) on the grounds of EU asylum law.

56 See B and D, supra, at para 89 et seq. 
Offering a wider personal scope of subsidiary protection, the analyzed judgment presents an excessive interpretation, one which ignores the letter of the law. For this reason alone, the judgment in the Diakite case deserves strong criticism. Moreover, the judgment may have a negative impact on the attitudes of the EU's Member States, which already consider the present state of EU asylum law to be excessively protective (and, consequently, excessively burdensome for State authorities ${ }^{57}$ ). Such practices appear to question the fundamental principle of legal certainty and the stable operation of Member States' bodies, as well as to undermine the trust placed in the European Union and its law. Grounding its decision on the broadly-defined objective of the Qualification Directive and choosing to adopt an autonomous definition of 'armed conflict', the Court concluded that further groups of foreigners require State protection, even though this is not provided for expressis verbis by any act of EU law.

While the harmonization criteria applied by Member States for identifying persons genuinely in need of international protection is one issue, deliberately ignoring the joint agreements on the common Area of Freedom, Security and Justice is a different matter altogether. It is beyond any doubt that, for the past several years, the political and social climate (in particular, the mood within the European Union) has been disadvantageous to further development of immigration and asylum policy at the EU level. Instead of being merely an introduction to the harmonization of immigration and asylum procedure standards, the set of legal instruments adopted at the turn of the twenty-first century - forming part of the implementation of the Tampere conclusions - also remained to serve as the ultimate point of reference in the second decade of the century. ${ }^{58}$

57 EU Member States are obliged to grant to a beneficiary of subsidiary protection a proper residence permit and provide him or her, inter alia, with material assistance.

${ }_{58}$ An illustrative example being the consultation process preceding the revision of EU Directive on the right to family reunification, where the re-opening of the Directive was abandoned in the fear that its solutions would not be made more liberal, but instead become even stricter; see M. Szuniewicz, W poszukiwaniu zalecanego kierunku zmian $w$ zakresie łączenia rodzin obywateli państw trzecich $w$ Unii Europejskiej - uwagi na tle Zielonej księgi z 2011 roku (Green paper COM(2011) 735) [Searching for the Recommended Direction of Changes in the Family Reunification of Third-country Nationals in the European Union - Remarks on the Green Paper (COM(2011) 735)], [in:] O. Łachacz, J. Galster (eds.), 'Status cudzoziemca w prawie międzynarodowym publicznym. Implikacje w prawie Unii 
The question remains, however, whether the standards of EU asylum policy can best be improved by adopting autonomous definitions and further exacerbating the fragmentation of international law. Advancing an interpretation that ignores the letter of the law is not a legitimate option where no consensus exists for adopting, under standard procedures, new regulations on the protection of third-country nationals. As much as the ideas expressed by the CJEU are undeniably important and deserve action on the agenda of EU organs, this is not a legitimate manner for them to be implemented; that is, at the expense of questioning the coherence of EU systems, undermining the trust and support of Member States, compromising the fundamental principle of the rule of law, and risking to increase the already-pronounced fragmentation of international law.

Europejskiej i polskim porządku prawnym' [Status of an Alien in Public International Law. Implications in the European Union Law and Polish Legal Order], Olsztyn 2014, p. 161, at pp. 171-172. 